\title{
O STAWANIU SIĘ (0)SOBĄ NA DRODZE PRZEZWYCIĘŻANIA SAMEGO SIEBIE. PROJEKT RADYKALNEJ ANTROPOLOGII (NEO)COACHINGOWEJ
}

\begin{abstract}
Streszczenie. Współczesny coaching dość dobrze sprawdza się w praktyce wychowawczej i terapeutycznej, ale brakuje mu solidnego fundamentu antropologicznego, to znaczy takiej koncepcji człowieka, która mogłaby stać się podstawą konstruktywnego (samo)rozwoju w duchu autentycznej wolności. Wydaje się, że w teorii coachingowej warto posłużyć się stworzoną przez Fryderyka Nietzschego koncepcją nadczłowieka. Oczekiwany przez Zaratustrę-Nietzschego nadczłowiek jest człowiekiem, który przezwyciężył własne słabości i potrafi twórczo działać w świecie, kierując się poczuciem odpowiedzialności za Ziemię. Korzystając z tej koncepcji (nad)człowieka, coach mógłby skutecznie pomagać swym podopiecznym i wychowywać ich „ku wolności”, zarazem nie uzależniając ich od żadnej doktryny psychologicznej, społecznej czy etycznej.
\end{abstract}

Słowa kluczowe: coaching, antropologia filozoficzna, Nietzsche, nadczłowiek, wieczny powrót, samoprzezwyciężenie, wolność

1. Wprowadzenie. 2. Antropologiczne podstawy współczesnego coachingu. 3. Wolny i twórczy (nad)człowiek wielką nadzieją coacha. 4. Syzyfowa praca coacha z wiecznie powracającym małym człowiekiem. 5. Zakończenie.

\section{WPROWADZENIE}

Nic nigdy nie jest aż tak dobre, że już nie może być lepsze. Wychodząc od tej dewizy, staram się przyjrzeć współczesnemu coachingowi pod kątem jego podstaw antropologicznych. Wszystko wskazuje bowiem na to, że mają one bardzo duży wpływ na skuteczność szeroko pojętego procesu pajdetycznego, w trakcie którego nie tylko przyswajamy sobie określone wzorce zachowań i zdobywamy wiedzę oraz kompetencje w zakresie niezbędnym do aktywnego i owocnego uczestniczenia w życiu społecznym i zawodowym, ale także, a nawet 
przede wszystkim, wszechstronnie formujemy siebie, stopniowo wcielając w życie uniwersalnie pojętą ideę człowieczeństwa, dzięki czemu coraz bardziej humanizujemy siebie i otaczający nas świat. Na kanwie prac Wernera Jaegera można powiedzieć, że paideia, kojarzona $\mathrm{z}$ wychowaniem bądź z kulturą starożytnej Grecji, posiada swoją własną dynamikę i rozsadza sztywne ramy wychowania i kultury. Staje się ona wiecznotrwałą osnową samorozwoju i samodoskonalenia człowieka wszystkich epok, mającą bardziej zasadnicze znaczenie niż przemyślne strategie rozwoju powstające w obrębie, a czasem na obrzeżach, współczesnych nauk szczegółowych. Wydaje się, że o ile $\mathrm{w}$ okresie antycznym funkcje pajedetyczne pełnili filozofowie, dla których filozofia była rodzajem sztuki życia albo - używając nader trafnego określenia wprowadzonego przez Pierre’a Hadota - ćwiczeń duchow(n)ych, o tyle obecnie misję swych zacnych poprzedników mogliby przejąć coachowie (filozoficzni), krzewiący idee prawdziwej mądrości życiowej. Zapewne wielu z nich stara się już to czynić, choć trudno określić, na jaką skalę się to dokonuje, ponieważ współczesny coaching jest bardzo zróżnicowany. Mamy do czynienia z rozmaitymi postawami i nastawieniami do tego szczególnego powołania czy też do tej szczególnej profesji. Widzimy coachów, którzy z poświęceniem towarzyszą ludziom $\mathrm{w}$ ich zmaganiach $\mathrm{z}$ własnymi słabościami i wspierają ich na każdym kroku. Widzimy również coachów, którzy z determinacją realizują własną wizję człowieka sukcesu i zachęcają ludzi do robienia kariery zawodowej. Jedni coache, jak Sokrates, prowadzą trudne rozmowy z przypadkowo napotkanymi ludźmi i, nie dbając o zarobek, chodzą, jak on, w wytartym ubraniu. $Z$ kolei inni coache, może trochę podobnie jak Protagoras, przygotowują precyzyjne plany biznesowe, zakładają własne przedsiębiorstwa doradcze i promują swą działalność głównie w obrębie firm gotowych słono płacić za takie usługi. Nie zamierzam oceniać ani intencji, ani sposobu pracy coachów. Gdyby przyjąć, że fenomen współczesnego coachingu, z szerokim spektrum jego różnorodnych cech, jest rodzajem igrzysk, podczas których jedni zabiegają o sławę, inni o pieniądze, 
a niektórzy tylko przypatrują się wszystkiemu, chcąc dociec istoty rzeczy $^{1}$, to chciałbym należeć do trzeciej z wymienionych kategorii ludzi, aczkolwiek może tym różnię się od Pitagorasa, że odczuwam potrzebę zwrócenia uwagi wszystkim osobom uczestniczącym w tych igrzyskach na ważne problemy związane $\mathrm{z}$ coachingową praktyką, a zwłaszcza na zagrożenie wolności człowieka dokonującego kluczowych wyborów życiowych. Zauważam bowiem, że podczas sesji wychowawczej (treningu, warsztatów itp.) coach może przekazywać swemu podopiecznemu nie tylko określone idee rozwoju i wzorce zachowań, ale także poglądy, które uprzednio sam zinternalizował. W ten zaś sposób może uzależnić go od doktryny, którą przyjmuje za słuszną, a nawet uzależnić go od siebie jako nauczyciela tej doktryny. Przyznaję, że w znanych mi metodach coachingowych nie dostrzegam sposobu skutecznego zabezpieczenia się przed możliwością zaistnienia takiego błędnego koła. Spróbuję zatem wykorzystać filozofię Fryderyka Nietzschego do zarysowania projektu zrewidowanego coachingu, który można by chyba nazwać neocoachingiem. Uzasadnieniem propozycji wykorzystania akurat tej radykalnej filozofii do celów coachingowych jest fakt, że Nietzscheańskim priorytetem pozostaje wolność powiązana z odpowiedzialnością za nas samych i za Ziemię. Również wymóg samoprzezwyciężenia, pozornie niezgodny z duchem wolności, służy w niej do wyzwolenia się ze wszystkiego, co osłabia naszą wolę i uniemożliwia rozwój ku twórczej wolności (nad)człowieka. Co więcej, w końcu prorok-coach Zaratustra uwalnia swych uczniów od siebie jako mistrza, przekonując ich, że sami mają się stać własnymi mistrzami, a więc mają dorosnąć do roli (nad)ludzi będących właściwym sensem Ziemi. W moim przekonaniu filozofia Nietzschego spełnia wymogi „ćwiczeń duchowych” i potrafi sprostać zadaniom pajdetycznym.

1 M.T. Cicero, Rozmowy tuskulańskie, w: tenże, Pisma filozoficzne, t. III, tłum. złac. W. Kornatowski, Warszawa 1961, 687 (V 3,8-10). 
Z uwagi na wielką różnorodność metod współczesnego coachingu, trudno jest dociec, jakie naprawdę są jego pierwsze zasady. W dość bogatej już literaturze przedmiotu dominuje tendencja do uwypuklania tych elementów różnych teorii, które, w opinii poszczególnych autorów, najlepiej sprawdzają się w praktyce. Takie podporządkowanie teorii praktyce jest w tym wypadku w pełni zrozumiałe. Poniekąd przymusza ono jednak antropologów filozoficznych, będących teoretykami, do stosowania niekonwencjonalnych procedur badawczych. W niniejszym opracowaniu przyjmuję, że wspólną płaszczyzną porozumienia między wszystkimi coachami powinny być ogólne ramy programowe nakreślone przez International Coach Federation (ICF) - naczelną organizację zrzeszającą osoby wykonujące tę profesję. Ponadto, skrótowo rekonstruując dzieje coachingu, stosuję metodę genealogiczną w znaczeniu, jakie temu słowu nadał Nietzsche, aby całość wywodu była wystarczająco spójna metodologicznie. W końcu zaś staram się, aby sam wywód był dostępny dla wszystkich osób zainteresowanych coachingiem, stąd świadomie stronię od wyrafinowanej, a przez to hermetycznej terminologii filozoficznej.

\section{ANTROPOLOGICZNE PODSTAWY WSPÓłCZESNEGO COACHINGU}

Na polskiej stronie internetowej ICF czytamy: „Coaching jest metodą pozwalającą w sposób efektywny wytyczyć i osiągnąć ważne cele, podnieść satysfakcję z życia zawodowego i prywatnego, stać się bardziej świadomym liderem, managerem, czy rodzicem. W pełni wykorzystuje potencjał, kompetencje i umiejętności klienta. Identyfikuje trudności. Przygotowuje do ich pokonania. Często przekłada się na motywację i większą determinację $\mathrm{w}$ działaniu. ICF definiuje coaching jako towarzyszenie klientowi w kreatywnym procesie, który skłania do myślenia i inspiruje do maksymalizacji zawodowego 
i osobistego potencjału"2. Również w ulotce promującej coaching podana została odpowiedź na pytanie, czym jest coaching: „Zgodnie $\mathrm{z}$ definicją ICF coaching określa pracę z klientami w ramach twórczego i skłaniającego do refleksji procesu, który inspiruje klientów do jak najpełniejszej realizacji ich potencjału w życiu zawodowym i osobistym”3. W powyższych sformułowaniach razi słowo „klient”, zaczerpnięte $z$ terminologii kupieckiej bądź żargonu psychoanalitycznego, choć trzeba przyznać, że jest ono jakoś zasadne, ponieważ kładąc się na kozetce, czy też siadając w fotelu naprzeciw coacha, podobnie jak siadając $\mathrm{w}$ fotelu dentystycznym, człowiek staje się klientem komercyjnej placówki, w której płaci się za zajęty czas i (z)użyte materiały, w tym i za zużyte nerwy psychoanalityka i coacha, którzy muszą słuchać długich i pewnie nierzadko nieskładnych wynurzeń swych interlokutorów. Można by to określenie potraktować $\mathrm{z}$ rezerwą, a nawet żartobliwie, stawiając je na równi z określeniem "gość". W języku potocznym mówi się czasem, że jakiś klient czy gość coś zrobił albo czegoś nie zrobił. Tak czy inaczej, na ogół kontekst jest zabawny i niezobowiązujący, tak więc nawet gdy ów klient czy gość uczestniczy w rozmowie, na ogół się nie zżyma na to dziwaczne nazewnictwo, tylko przyjmuje je z przymrużeniem oka. Aczkolwiek - poważnie podchodząc do sprawy - warto by się w tym kontekście zastanowić, czy rozmowy z coachami powinny być odpłatne. Wydaje się, że pracę coacha, tak jak pracę pracownika socjalnego jakiejś instytucji użyteczności publicznej, albo jak pracę lekarza bądź misjonarza działającego w krajach trzeciego świata, lepiej opłacać z innego źródła

2 Zob. https://icf.org.pl/. Wprawdzie ICF w Polsce ma też nazwę Stowarzyszenie Trenerów Rozwoju Osobistego, jednak działacze tej federacji wyraźnie preferują posługiwanie się angielską terminologią, stąd pojęcia „coaching” i „coach” właściwie są wszechobecne i praktycznie nie mają polskich odpowiedników. Funkcjonujące na naszym gruncie doradztwo filozoficzne, mimo analogicznej misji, jaką pełni, sprawia wrażenie odrębnej specjalności. Wydaje się, że angielskie nazewnictwo jest elementem marketingowej strategii, konsekwentnie stosowanej przez ICF.

3 Cytuję firmowaną przez ICF ulotkę Uwolnij potencjał, rozprowadzaną podczas szkoleń coachingowych. 
niż portfel człowieka, który akurat znalazł się w życiowych tarapatach i gorączkowo szuka pomocy. Skoro ICF jest organizacją non profit ${ }^{4}$, to i skupieni $\mathrm{w}$ tej organizacji coache też powinni udzielać się non profit, a pieniądze na tę działalność powinny pochodzić ze skarbu państwa albo z jakiejś fundacji. Profesjonalnych coachów ewentualnie mogłyby zatrudniać bogate korporacje, w których przyczynialiby się oni do wzrostu wydajności pracy i pomnażania zasobów finansowych firmy. Niemniej podejmowanie takiego zatrudnienia wiąże się z dylematami o charakterze moralnym, jako że w korporacjach coach jest potrzebny raczej nie po to, by ludziom pomagać, ale po to, by ich wyciskać jak cytryny, co powoduje, że wraz z kadrą kierowniczą korporacji stanowi, w jakimś sensie, bezduszne narzędzie opresji.

Zgodnie z definicją coachingu, naczelnym zadaniem coachów jest pomaganie ludziom w „realizacji ich potencjału”. Słowo „realizacja”, wielokrotnie pojawiające się w tekście ulotki, należy do nowomowy, która w dzisiejszych czasach pustoszy nie tylko sam język, ale też cała sferę międzyludzkiej komunikacji. Autorzy ulotki czy też definicji ICF niewątpliwie mieli na myśli rozwój potencjału, a nie realizację potencjału. Pewnie ta niezręczność stylistyczna wzięła się z chęci posłużenia się spopularyzowanym przez psychologów pojęciem „samorealizacji”. Profesjonalni coache chyba jednak nie oczekują tego, że klienci będą się sami realizować, ponieważ gdyby tak zaczęło się dziać, to staliby się po prostu niepotrzebni. Zastrzeżenia budzi również stwierdzenie, że ludzki potencjał należy rozwijać w życiu zawodowym i osobistym. Jest rzeczą oczywistą, że należy rozwijać go w sobie, a więc w sferze przynależącej do życia osobistego. Jeżeli tam będzie się właściwie rozwijał, to i na pewno - wtórnie - zagości w sferze życia zawodowego. Wysunięcie życia zawodowego na

4 Przynajmniej tak jest w Polsce, co zostało wyraźnie zaznaczone w ulotce. W Statucie Stowarzyszenia, zamieszczonym na polskiej stronie internetowej ICF, w par. 2 pkt. 12 i 13 jest tylko, ogólnie, mowa o promowaniu działalności charytatywnej i wolontariatu; zob. https://icf.org.pl/o-nas/statut-stowarzyszenia/. 
pierwszy plan zapewne podyktowane zostało wolą skomercjalizowania procesu coachingowego. Intencję tę widać już bardzo wyraźnie w drugiej części odpowiedzi na pytanie, czym jest coaching: „Proces coachingowy wspiera w rozwijaniu umiejętności przywódczych, managerskich i biznesowych. Może też uwolnić osobisty potencjał, zwiększyć perspektywy zawodowe w firmie lub na rynku pracy. Przełożyć się na poprawę jakości i zadowolenia z życia”. Tutaj świetlane perspektywy osiągnięcia sukcesu w życiu zawodowym wręcz kłują $\mathrm{w}$ oczy $^{6}$, podczas gdy ewentualny sukces wynikły z rozwijania osobistego potencjału i w ogóle życia osobistego wyraźnie schodzi na dalszy plan i przyjmuje formę czegoś warunkowego, możliwego do osiągnięcia w drugiej kolejności, ale już nie gwarantowanego przez coacha.

Przyjęty przez ICF punkt widzenia pozostaje obcy podejściu humanistycznemu. Dla humanistów fundamentalne znaczenie ma rozwijanie w duchu wolności ludzkich predyspozycji i uzdolnień, stawanie się sobą, czyli autonomicznym podmiotem, potrafiącym samodzielnie i w zgodzie z samym sobą myśleć oraz postępować. Ten pajdetyczny pogląd, znany od zarania ludzkich dziejów, bardzo mocno pobrzmiewa w filozofii Rousseau, a także we współczesnej antypedagogice. Harmonizuje z nim przekonanie, że każdy człowiek potrafi zadbać o swój własny rozwój, o ile wyposaży się (go) w wiedzę, czym ten rozwój jest. Tę kwestię filozofowie dobrze znają dzięki Platonowi, który pokazał, jak jego mistrz - Sokrates - traktował cnotę (arete). Pozwolę sobie przypomnieć, że dla Sokratesa cnota jest czymś, co można teoretycznie zrozumieć, a potem praktycznie sobie przyswoić. Zgodnie z powszechnie panującym w jego czasach przekonaniem, ludzie rodzą się cnotliwi albo rodzą się pozbawieni

5 Ulotka Uwolnij potencjał.

6 Nader znamienny jest fakt, że na stronie ICF oraz na ulotce zamieszczone zostały zdjęcia przedstawiające szeroko uśmiechniętych ludzi sukcesu, których postawa ciała od razu kojarzy się z wielkimi przywódcami i managerami. 
cnoty. Za taki stan rzeczy odpowiada los (przeznaczenie, Ananke). To on sprawia, że właściwie nie mamy żadnej władzy nad sobą i musimy pogodzić się z tym, że jesteśmy tacy, jacy jesteśmy. Sokrates sprzeciwił się temu antropologicznemu pesymizmowi i pasywnemu samooglądowi. Jego propozycja jest $\mathrm{z}$ ducha optymistyczna: Każdy człowiek może rozwijać $\mathrm{w}$ sobie różne wartościowe cnoty i dzięki nim osiągać w życiu szczęście. Mniej ważne jest, z czym albo bez czego się urodziliśmy, ponieważ najważniejsze jest to, co sami z własnym życiem chcemy począć. $Z$ koncepcji tej wynika, że nawet „urodzeni” przestępcy mogą się nawrócić $\mathrm{i}$ uwierzyć $\mathrm{w}$ siebie - w to, kim się staną, gdy będą nad sobą pracować i przeobrażać samych siebie w jakościowo lepszych ludzi.

Historycznie rzecz biorąc, pogląd Sokratesa został przejęty przez Platona i powiązany z wyobrażeniem świata idei jako miejsca okalającego jego główną ideę Dobra, czyli ostoi wszelkiej cnoty. Innymi słowy, tak jak każda idea jest doskonałym wzorcem odpowiadających jej przedmiotów istniejących w naszym zmysłowo poznawanym świecie, tak w szczególności idea Dobra jest doskonałym wzorcem czy, lepiej, wzorem dobra rodzącego się w nas samych i kształtującego nas na porządnych, a więc cnotliwych ludzi, którzy dobrze sobie radzą w życiu osobistym i zawodowym. Za sprawą neoplatończyków pogląd ten przeniknął do chrześcijaństwa, które utożsamiło idę Dobra z Bogiem, który z natury jest dobry, a przez to jest samym dobrem (summum bonum, jak potem pisał św. Tomasz). Dla chrześcijan, patrzących przede wszystkim oczyma wiary, a nie tylko oczyma historyka idei', Jezus Chrystus jest prawdziwym Nauczycielem, zaś Ewangelie są wiedzą o tym, jak należy żyć. Można by powiedzieć, że jest on prawdziwym Coachem, który nieustannie mówi nam o tym, co jest dla nas najważniejsze. $Z$ jego pomoca potrafimy aktywnie

7 Pewnie nic nie stoi na przeszkodzie, żeby w tym miejscu zacytować słowa zaczerpnięte z ballady Romantyczność: „Czucie i wiara silniej mówi do mnie niż mędrca szkiełko i oko”. A. Mickiewicz, Wiersze, Warszawa 1970, 69. 
rozwinąć nasz potencjał i stać się sobą par excellence. Jakkolwiek by się zapatrywać na religijny model wychowania, obiektywnie trzeba przyznać, że wielu coachów, mających wielkie poważanie w tym środowisku, wywodzi się z kręgów chrześcijańskich - zwykle z charyzmatycznych wspólnot protestanckich, w których za sprawą Ducha Swiętego dokonują się wielkie cuda ludzkich nawróceń i spektakularnych przemian wewnętrznych, owocujących widocznym poczuciem życiowego spełnienia i szczęścia ${ }^{8}$. Wiele wskazuje na to, że coaching jako taki, ze swym spontanicznym i niemal ekstatycznym rysem, wyrósł na gruncie działalności ewangelizacyjnej i misjonarskiej, czym odróżnia się od tradycyjnej psychoterapii, zastygłej w iście szkolnych, sformalizowanych schematach. Nowoczesne Kościoły protestanckie nierzadko dbają też o całościowy rozwój człowieka, włączając do swej posługi duszpasterskiej szkolenia z zakresu zdrowego trybu życia9, które w znacznym stopniu przyczyniają się do poprawy jakości życia w wymiarze somatycznym, a przez to mają niewątpliwy walor

8 Z pentekostalnego nurtu chrześcijaństwa chyba najbardziej znany jest Kościół Zielonoświątkowy, ale także w innych Kościołach protestanckich tego typu ma dochodzić do szczególnego objawiania się mocy Ducha Świętego, do mówienia „anielskimi” językami (glosolalia) i do radykalnej zmiany stylu życia członków zborów. Ze względów edukacyjnych nawet niewierzącym i „wierzącym inaczej” coachom warto polecić lekturę książek opisujących te niecodzienne fenomeny, np. M. Harper, Tak jak na początku. Z dziejów przebudzenia pentekostalnego wXX wieku; J. i E. Sherrill, Najszczęśliwsi na świecie. Fascynująca historia Demosa Shakariana. Należy dodać, że podobne świadectwa pojawiają się również w obrębie katolickiego Ruchu Odnowy w Duchu Świętym.

9 Kościół Adwentystów Dnia Siódmego słynie z szerokiej oferty kursów dla osób uzależnionych od alkoholu i tytoniu, dla osób chcących się odstresować czy prawidłowo odżywiać. W ramach Zarządu Kościoła aktywnie działa Sekretariat Zdrowia i regularnie wydawany jest biuletyn Chronimy zdrowie. Kwestie zdrowotne wchodzą w skład doktryny religijnej Kościoła Adwentystów Dnia Siódmego, co potwierdza pastor Zachariasz Łyko: „Człowiek - w myśl nauki Pisma Świętego - stanowi jedność psychosomatyczną i w całości jest tworem Bożym. W świetle teologii biblijnej ciało nie jest elementem negatywnym, czymś w rodzaju więzienia duszy. Przeciwnie, stanowi ważne podłoże rozwoju duchowego. Obowiązkiem chrześcijanina jest prowadzić zdrowy tryb życia. Jest to przede wszystkim obowiązek religijny, mający za sobą powagę Boga, jak również cenny z punktu widzenia społecznego". Z. Łyko, Nauki Pisma Świętego, Warszawa 1989, 539. 
wychowawczy i terapeutyczny. Skoro jest mowa o oddziaływaniach terapeutycznych, to nie sposób chociaż nie wspomnieć o dobroczynnych skutkach dla organizmu, a więc i całego człowieka, stosowania technik medytacyjnych i relaksacyjnych, zaczerpniętych z buddyzmu i hinduizmu ${ }^{10}$.

Dzisiaj, gdy borykamy się z mnogością problemów nie występujących na tak wielką skalę wcześniej, w tym przede wszystkim problemów cywilizacyjnych, generujących kolejne problemy (nadmierne stechnicyzowanie ludzkiego życia, stresogenny model zatrudnienia i wykonywania pracy zawodowej, zanieczyszczenie środowiska naturalnego, masowa migracja ludności itp. ${ }^{11}$ należy korzystać $z$ wielu różnych sposobów pomagania ludziom w ich rozwoju i stwarzania dobrych warunków do ich samorozwoju. Posługiwanie się różnymi dostępnymi metodami szeroko pojętego wychowania nie jest w tym wypadku przejawem eklektyzmu, gdyż ten charakteryzuje schyłkowy etap jakiejś epoki w dziejach kultury. Jest ono raczej wymogiem ekumenii ${ }^{12} \mathrm{~W}$ warunkach zintensyfikowanego rozwoju i procesu jednoczenia, scalania i totalizowania ludzkości ${ }^{13}$. Przyzwyczailiśmy się już do funkcjonowania w "globalnej wiosce”, będącej wirtualnym

10 Na Uniwersytecie Opolskim każda osoba znajdująca się w potrzebie może otrzymać fachowe wsparcie wykwalifikowanych coachów (zwłaszcza Piotra Leśniaka i Grzegorza Francuza). Temu celowi służy specjalne pomieszczenie przeznaczone do prowadzenia rozmów terapeutycznych (Pogadalnia), usytuowane przy gabinetach naszych filozofów. Ponadto Francuz, będący znawcą buddyzmu, prowadzi cieszące się dużym zainteresowaniem studentów zajęcia z technik oddychania i medytowania.

11 Martin Heidegger powiedziałby - „w dzisiejszej biedzie świata”; zob. M. Heidegger, List o „humanizmie”, tłum. z niem. J. Tischner, w: tenże, Znaki drogi, Warszawa 1995, 168.

12 Posługuję się trafnym, moim zdaniem, pojęciem „ekumenia” (oikumene), które znaczy „zamieszkana Ziemia” i wskazuje na wspólnotę bycia (życia) wszystkich ludzi oraz potrzebę troski i odpowiedzialnego współdziałania na rzecz błękitnej planety, będącej naszą matką-żywicielką. Etymologicznie pokrewnym pojęciem, od którego abstrahuję, jest „ekumenizm”, wyrażający wolę zacieśniania duchowej więzi między poszczególnymi odłamami chrześcijaństwa za pomocą dialogu i modlitwy.

13 Pierre Teilhard de Chardin SJ uważał sukcesywnie następującą i niemożliwą do powstrzymania totalizację ludzkości za podstawowe zjawisko na Ziemi; zob. P. Teilhard de 
obszarem komunikacji i zasobem wiedzy dostępnej dla wszystkich ludzi (Internet). W ten sposób, w pewnym sensie, wróciliśmy do źródeł, ponieważ, wbrew obiegowym opiniom, początki naszej cywilizacji nie są rozpoczynaniem wszystkiego od nowa, tylko są początkiem rozwijania przez nas tego wszystkiego, co jako nowe zostało przejęte od wcześniejszych wielkich kultur. Idee „powstałe” w basenie Morza Śródziemnego w rzeczywistości powstały na Dalekim i Bliskim Wschodzie. Ściślej biorąc, filozofia i nauka grecka zostały ufundowane na filozofii i nauce mezopotamskiej, hinduistycznej, egipskiej i wielu innych. Kreatywna wymiana owych idei oraz ich dalszy rozwój dokonuje się w obrębie wspomnianej wcześniej ekumenii. Teraz przychodzi czas na zglobalizowanie naszego rzeczywistego (miejsca do) życia i patrzenie na Ziemię jak na jedną wielką „wioskę”, w której musimy poczuć się swojsko, tj. doświadczyć prawdziwego bycia (życia) (o)sobą i u siebie. Zadania tego powinni podejmować się specjaliści z różnych dziedzin, między innymi coache.

\section{WOLNY I TWÓRCZY (NAD)CZŁOWIEK WIELKĄ NADZIEJĄ COACHA}

Mimo iż - ogólnie rzecz biorąc - współczesny coaching zasługuje na pozytywną ocenę, należy też dostrzec jego istotne mankamenty. Jednym z nich jest podporządkowanie całego procesu ludzkiego rozwoju pragmatycznie określonemu celowi tego rozwoju, którym jest uczynienie człowieka istotą osiągającą w życiu sukcesy i przez to szczęśliwą. Chyba niewiele trzeba, żeby wzniosłe, ale zarazem nazbyt ogólnikowe ideały coachingowe zostały wykrzywione i świadomie zmanipulowane. Wykorzystując techniki coachingowe, dość łatwo można szerzyć niebezpieczne ideologie. Wystarczy bowiem ukierunkować bezradnego i zagubionego w życiu człowieka na cele odpowiadające jakiejś niebezpiecznej sekcie religijnej, partii politycznej

Chardin, Moja wizja świata, w: tenże, Moja wizja świata i inne pisma, tłum. z fr. M. Tazbir, Warszawa 1987, 177 i 182. 
czy grupy anarchistycznej albo terrorystycznej. Wtedy będzie się on życiowo spełniał jako wojujący fundamentalista, anarchista albo terrorysta; i w tym, co będzie robił, odnajdzie szczęście, którego wcześniej nie zaznał. Słabością coachingu, tak jak słabością coachowanego człowieka, jest brak zakorzenionej w życiu i służącej życiu filozofii. Nie chodzi o wydumaną, spekulatywną filozofię życia, ale o filozofię wyrastającą z życia, a więc zgodną z nim. Dobrym - jak sądzę przykładem może być filozofia Fryderyka Nietzschego. Obiektywnie rzecz biorąc, Nietzsche - w czasie, gdy jeszcze nie stworzył własnej filozofii życia - świetnie nadawałby się na klienta jakiegoś gabinetu psychoterapeutycznego albo coachingowego. Ten chorowity, trochę zagubiony w realiach świata i zdziwaczały człowiek borykał się z wieloma problemami, które jakby go przerastały. On jednak nie poddawał się, a własne słabości uczynił narzędziami cielesno-duchowej odnowy. Jego własne doświadczenia życiowe zaowocowały nową wizją (nad)człowieczeństwa, skuteczne rozprawiającego się ze wszelkimi słabościami. Dość dużo wiedzy na temat zachodzącego w nim procesu samoprzezwyciężania zawiera autobiograficzne dziełko Ecce homo, napisane już z perspektywy odniesionego sukcesu życiowego (jeżeli można posłużyć się takim sformułowaniem). Elementy składające się na Nietzscheańską koncepcję człowieka zawarte są w jego licznych pracach i bogatej spuściźnie, ale kluczowe pod tym względem jest quasi-biblijne ${ }^{14}$ dzieło Tako rzecze Zaratustra, przybliżające enigmatyczną ideę nadczłowieka i skorelowaną z nią ideę wiecznego powrotu. Dzięki przystępnej formie stało się ono bardzo popularne i w zasadzie jest czytane przez wszystkich. Nie znaczy to jednak, że równie przystępna jest treść tego dzieła. Zawiera się w nim bowiem wiele poziomów rozumienia i interpretacji, za którymi dopiero

14 W liście do wydawcy Nietzsche nazwał je „piątą " ewangelią" ( fünftes „Evangelium”); zob. KSB 6, 327 (375. An Ernst Schmeitzner in Chemnitz; Rapallo, 13. Februar 1883). Skrót KSB oznacza krytyczne wydanie listów Nietzschego: Sämtliche Briefe. Kritische Studienausgabe in 8 Bänden, red. G. Colli, M. Montinari, Berlin 1986. 
skrywa się właściwe przesłanie filozoficzne Nietzschego. Jest to więc bez wątpienia książka dla wszystkich i dla nikogo, co potwierdza także jej podtytuł. Nietzsche powiada, że nie tyle sam się trudził nad obmyślaniem fabuły czy konstruowaniem wywodów, ile raczej sama rzeczywistość życia przychodziła do niego i układała się w jego głowie w literacko piękne i filozoficznie wnikliwe przypowieści. Ten inspirowany życiem proces twórczy jest niezwykle tajemniczy: „Wszystko dzieje się w najwyższym stopniu niedobrowolnie, ale jakby w szturmie poczucia wolności, bezwarunkowości, mocy, boskości"15.

Głównym bohaterem wspomnianego dzieła jest Zaratustra ${ }^{16}$ swego rodzaju prorok, nauczyciel lub coach, który w wieku trzydziestu lat udał się w góry, by samotnie rozmyślać nad światem, a po dziesięciu latach zszedł w doliny do ludzi, chcąc dzielić się z nimi swą mądrością życiową. Niegdyś niósł on swoje popioły w góry, dzisiaj zaś znosi swój ogień w doliny, a więc może się okazać, że będzie podpalaczem świata ${ }^{17}$. Samotność zmieniła Zaratustrę i teraz z przygaszonego człowieka znowu przeobraził się w dziecko czy też w człowieka przebudzonego, który idzie do tych, co jeszcze śpią ${ }^{18}$. Mowy Zaratustry rozpoczynają się od przedstawienia przemian, jakie zachodzą w duchowej sferze indywidualnego człowieka, o ile jego rozwój przebiega prawidłowo. Do pewnego stopnia są one także porównywalne $\mathrm{z}$ historycznie rozumianymi przemianami $\mathrm{w}$ mentalności całej społeczności ludzkiej. Jak się wydaje, można mówić

15 KSA 6, 340 (Ecce homo: Also sprach Zarathustra, 3). Skrót KSA oznacza krytyczne wydanie dzieł F. Nietzschego: Sämtliche Werke. Kritische Studienausgabe in 15 Bänden, red. G. Colli, M. Montinari, Berlin 1988. Korzystam z tekstu oryginalnego, ponieważ młodopolskie wydanie Mortkowicza jest już językowo nazbyt archaiczne, a nowsze tłumaczenia poszczególnych dzieł nie są wystarczająco spójne terminologicznie.

16 Mohammad Azadpur obszernie pisze na temat perskiej moralności oraz związku Nietzscheańskiego Zaratustry z perskim prorokiem Zartosht (Zoroaster); zob. M. Azadpur, Who is Nietzsche's Zarathustra? On Philosophy, Morality, and the Persians, New Nietzsche Studies 3(1999), 69-82.

17 Zob. KSA 4, 12 (Also sprach Zarathustra: Zarathustra's Vorrede, 2).

18 Tamże. 
o kolejno następujących po sobie, coraz wyższych fazach rozwoju, które prowadzą do pełnej, tj. twórczej wolności ducha. Aby duch mógł stać się naprawdę wolny, musi najpierw doświadczyć tego, czym jest zniewolenie, jak również uporać się z własnym destrukcyjnym działaniem wobec mniej lub bardziej realnego źródła owego zniewolenia. W konsekwencji, zanim duch dosięgnie granic twórczej wolności, musi przez jakiś czas dźwigać na sobie brzemię zniewolenia, aby potem zrzucić je z siebie i przez jakiś czas szerzyć wokół duchowe spustoszenie. Powyższą idę̨ Nietzsche zawarł w wielce znamiennej metaforze $O$ trzech przemianach, która opisuje, jak duch staje się wielbłądem, wielbłąd lwem, a lew dzieckiem ${ }^{19}$.

Pierwszym etapem rozwoju jest stadium nieuświadomionego zniewolenia, przedstawione na przykładzie wielbłąda. Zwierzę to bez sprzeciwu pozwala obładować siebie wielkimi ciężarami i pokornie nosi je na swym grzbiecie. Podobnie człowiek, reprezentowany przez wielbłąda, właśnie w (z)noszeniu ciężarów i pogodzeniu się z trudami życia widzi zadanie i cel własnej egzystencji. Do tego stopnia przekonany jest o słuszności takiej postawy, że nawet dobrowolnie podejmuje się dźwigania największych ciężarów i ponoszenia największego trudu. Ten niezwykle pokorny duch szuka tego, co ciężkie $\mathrm{i}$ trudne, ponieważ konfrontując siebie z ogromnymi zobowiązaniami, chciałby dowieść swej całkowicie dobrej woli. Jednak dobra wola względem zewnętrznych nakazów i przepisów jest w gruncie rzeczy złą wolą względem priorytetów wewnętrznego rozwoju duchowego.

19 Zob. KSA 4, 29 (Also sprach Zarathustra I: Von den drei Verwandlungen). Karl Jaspers przyrównuje trzy przemiany ducha do „trzech kroków” na drodze samorozumienia Nietzschego. Pierwszy z nich polegał na uwielbianiu innych i uczeniu się od nich. Młody filozof najbardziej podziwiał swych pierwszych nauczycieli, tj. Schopenhauera i Wagnera. Była to dla niego faza dzielności, czas wspólnoty. Drugi krok wiązał się z uzyskaniem wolności i niezależności. Charakteryzował się postawą krytyki wobec tego wszystkiego, co wcześniej wzbudzało w nim podziw. Trzeci krok był decyzją twórcy gotowego afirmować wytwory swej pracy. Naznaczony był postawą wielkiej odpowiedzialności i niewinności w świecie bez Boga; zob. K. Jaspers, Nietzsche. Wprowadzenie do rozumienia jego filozofii, tłum. z niem. D. Stroińska, Warszawa 1997, 38-39. 
Można się o tym przekonać w sytuacji, gdy wielbłąd coraz bardziej słabnie i w końcu staje się prawie bezsilny i niezdolny do uporania się z nałożonym ciężarem. Bezsilność nie budzi w nim pragnienia buntu, lecz wytwarza poczucie winy, które jest przyczyną duchowego zamykania się w sobie. Mimo iż wielbłąd znajduje się już na skraju wyczerpania, nie chce sobie ulżyć, a tym bardziej nie chce dać sobie ulżyć. $Z$ niezmienną pokorą i niezrozumiałą dumą odsyła od siebie wszystkich tych, którzy chcą mu pomóc, bowiem najwyższą cnotą i wyrazem własnej wartości jest dla niego „być chorym i odesłać do domu pocieszycieli i zawrzeć przyjaźń z głuchymi, którzy nigdy nie słyszą"20 głosu swej ukrytej woli.

Symbolizując bezgraniczną cierpliwość, wytrwałość i gotowość poniesienia ofiary z samego siebie, wielbłąd okazuje się niezdolny do bycia naprawdę sobą. Postawa wyrzeczenia i pasywne godzenie się z losem nie prowadzi do wyzwolenia, ale pogłębia faktyczne zniewolenie. $Z$ czego zatem bierze się skłonność człowieka do bycia wielbłądem, a więc do poświęcenia, a nawet do zatracenia własnej egzystencji? Nietzsche sugeruje, że winna temu jest miłość, której potencjałem i mocą niewłaściwie się gospodaruje. „Tych kochać, którzy nami gardzą" ${ }^{21}$ nie jest oznaką dobroci dającej siebie innym, ale przykładem braku roztropności, zaprzepaszczającym prawdziwą wartość miłości. Jeżeli w swej mowie Zaratustra ostentacyjnie nie potępia przyjmowania postawy wielbłąda, to tylko dlatego, że zdaje sobie sprawę z konieczności posiadania tego rodzaju doświadczeń. Trzeba stać się choć na krótką chwilę wielbłądem, aby wewnętrznie dojrzeć do kolejnego stopnia duchowego rozwoju. Po przemianie w lwa znika problem marnotrawienia miłości, ponieważ lew nie obdarza nią nikogo innego poza sobą samym. Nieoczekiwanie pojawiająca się możliwość wzięcia sprawy w swoje ręce (czy w swoje łapy) również i lwa zamyka na otaczającą rzeczywistość, tyle że w zupełnie

20 KSA 4, 29 (Also sprach Zarathustra I: Von den drei Verwandlungen).

21 Tamże, 30. 
odmienny sposób niż wielbłąda. Radykalna aktywność nie chroni przed błędami całkowitej pasywności, dlatego lew zainteresowany jest wyłącznie sobą i własnym dobrem: „Chce zdobyć dla siebie wolność i być panem na swej własnej pustyni”22.

Smak nieskrępowanej wolności pozwala ewoluującemu duchowi stać się butnym lwem, ale nie pozwala jeszcze dostrzec, że celem jego pragnień jest jedynie wolność „od”, a nie wolność „do”. Lew nie potrafi twórczo wykorzystać uzyskanej wolności, ponieważ odkrył w sobie wyłącznie wolę niszczenia. O ile wielbłąd wykazał się wielkim poczuciem obowiązku, o tyle lwa charakteryzuje „święte "nie“ wobec obowiązku"23. Chciałby walczyć ze wszystkim i ze wszystkimi, aby tylko uwolnić się od jakichkolwiek zobowiązań, ponieważ nawet najmniejszy ciężar na grzbiecie przytłacza jego wolę wolności. Niczego nie uszanuje i niczego nie zachowa, a cokolwiek znajdzie na swej drodze, od razu zniszczy: „Zgłodniałą, brutalną, samotną, bezbożną: taką chce siebie wola lwa"24. Drapieżna natura lwa nie liczy się z żadnymi obcymi zasadami czy wartościami, lecz nie tworzy - bo też nie potrafi stworzyć - żadnych nowych zasad i wartości. Mimo iż całym sobą nastawiony jest na bezpośrednie działanie, nie zamierza zdziałać niczego, co służyłoby innym i miało walor ponadczasowości. Wielkim zagrożeniem dla egzystencji lwa jest samozatracenie się w nihilistycznej pustce, która swym śmiercionośnym oddechem już dusi go i obezwładnia. Jest to inna forma zniewolenia, paradoksalnie obecna akurat tam, gdzie na pierwszy rzut oka w ogóle nie brakuje wolności. Jeżeli lew nie opamięta się i nie odkryje w sobie woli tworzenia nowych wartości i nowych zasad postępowania, wówczas nie będzie dla niego ratunku. Sam zginie, a z czasem pustkę wypełnią dawne wartości i wszystko będzie po staremu. „Nazywasz siebie wolnym? Chcę usłyszeć twoją panującą myśl, a nie, że umknąłeś

22 Tamże.

23 Tamże.

24 KSA 4, 133 (Also sprach Zarathustra II: Von den berühmten Weisen). 
jarzmu"25, mówi Zaratustra. Gdy lew uświadomi sobie wreszcie pozorną wolność swego buńczucznego ,ja chcę" i zapragnie wydobyć z siebie twórczą wolę wolności, wówczas stanie się wystarczająco dojrzały do kolejnej przemiany.

$\mathrm{Na}$ najwyższym szczeblu duchowego wzrostu pojawia się wymóg autentycznego bycia sobą i postępowania w zgodzie z działaniami samej natury. Takiej wielkości duchowej może jednak dostąpić tylko ktoś, kto z racji swej małości nie ma pojęcia o żadnej wielkości, dlatego też nie da się zwieść wyrachowanym skłonnościom lub próżnym ambicjom. Jedynie dziecko lub ktoś, kto odczuwa i bawi się jak dziecko ${ }^{26}$, potrafi sprostać temu zadaniu, stąd Zaratustra nawołuje: "Chcę, aby twoje zwycięstwo (Sieg) i twoja wolność (Freiheit) pragnęły dziecka. Powinieneś budować swemu zwycięstwu i swemu wyzwoleniu (Befreiung) żywe pomniki”27. Wydaje się, że najistotniejszą cechą dziecka jest swoista niewinność stawania się, stale towarzysząca jego zabawie. Tam, gdzie dziecko bawi się, a równocześnie rękami dziecka bawi się sama natura, w naturalny sposób załamuje się wszelka metafizyka, wiara w statyczny byt i w niezmienne wartości. Dziecko żyje tylko aktualnością czasu teraźniejszego i staje się ucieleśnieniem twórczego istnienia, które całą mocą swej woli wprost bezgranicznie miłuje to życie, jakie dane jest $w$ tej akurat chwili. Tutaj nie pojawiają się już obawy związane z sensem, celem czy praktycznymi skutkami zabawy, ponieważ w jej istocie nie mieści się nic, co wykracza poza

25 KSA 4, 81 (Also sprach Zarathustra I: Vom Wege des Schaffenden).

26 Myśl o zabawie dziecka Nietzsche zaczerpnął z eposu Homera: „Tak kiedy chłopiec z piasku nad morzem / Ledwie kopiec usypie w dziecinnej igraszce, już zaraz / Burzy w zabawie, trącając budowlę rękami, nogami (Homer, Iliada, tłum. z gr. K. Jeżewska, Ossolineum, Wrocław 1986, s. 356 [pieśń piętnasta, 362-364]). Inspiracją dlań była również zawarta w filozofii Heraklita metafora zabawy, która przybliża istotę czasu: „Czas jest dzieckiem, które bawi się, przestawia kamyki z miejsca na miejsce”. H. Diels, Die Fragmente der Vorsokratiker. Griechisch und Deutsch, Berlin 1922, t. 1, 69 [B 52].

27 KSA 4, 90 (Also sprach Zarathustra I: Von Kind und Ehe). W języku niemieckim słowo sieg jest rodzaju męskiego, natomiast słowa Freiheit oraz Befreiung są rodzaju żeńskiego, co poniekąd uzasadnia mówienie o dziecku i żywych pomnikach. 
teraźniejszość chwili. Dlatego „niewinnością jest dziecko i zapomnieniem, rozpoczynaniem od nowa, zabawą (Spiel), z siebie toczącym się kołem, pierwszym poruszeniem, świętym mówieniem »tak«"28. Dziecko jest zapomnieniem, ponieważ z perspektywy czystego aktu bawienia się cały świat przeszły i przyszły traci rację bytu. Jest ono jednak również z siebie toczącym się kołem, a to oznacza, że zapomnienie staje się funkcją nieustannego przypominania sobie tego, co jest, jako tego, co już było wielokrotnie, a więc najprawdopodobniej jeszcze będzie wielokrotnie. Dziecko nie tylko zgadza się na to, aby w jego wiecznie wolnym duchu spirala czasu w nieskończoność wykręcała swe piruety, ale nawet afirmuje takie poczucie bezczasowości czasu. W tym względzie dziecko radykalnie różni się od lwa, ponieważ życie samo ofiaruje mu to, co lew musiał (chciał?) sobie wywalczyć, a mianowicie poczucie wewnętrznej wolności od czasowych barier i ograniczeń w zakresie tworzenia własnej jaźni.

Będąc absolutnie wolne, dziecko nie jest targane wewnętrznymi rozterkami i dylematami, pozostaje w zgodzie z sobą i dlatego wypełnia je niezmienny pokój. „»Jestem ciałem i dusząu - tak mówi dziecko"29 i oddaje się nastrojowi chwili, który pozwala rozpoznać otaczający świat jako ontyczną całość złożoną z nieskończonej ilości elementów. Tenże świat jest dla dziecka eksperymentalną przestrzenią zabawy, terenem dogłębnych penetracji i obiektem odkryć badawczych. Odkrywanie starego jest jednak zawsze tworzeniem nowego, a prawda ta najbliższa jest samej jaźni dziecka, stale na nowo tworzonej i rozbudowywanej przez niezmierzone dary życia. Bawiące się dziecko tworzy siebie w swym własnym świecie, chociaż nie byłoby to możliwe, gdyby nie pewność i gwarancja bezpieczeństwa dana mu ze strony innego świata, mianowicie świata dorosłych.

28 KSA 4, 31 (Also sprach Zarathustra I: Von den drei Verwandlungen). Niemieckie słowo Spiel można tłumaczyć jako zabawę lub grę. W kontekście nietzscheańskim chyba bardziej zasadne jest mówienie o zabawie, aczkolwiek w polskich przekładach dzieł tego myśliciela zwykle pojawia się słowo "gra”.

29 KSA 4, 39 (Also sprach Zarathustra I: Von den Verächtern des Leibes). 
Wypływająca stąd egzystencjalna dialektyka wewnętrznej samodzielności i zewnętrznego oparcia jest niezbywalną gwarancją rozwijania twórczych potencjalności dziecka. Jego jaźń stale chce tworzyć: „Tego chce najbardziej, to jest jej cała żarliwość”30. Podobnie jak małe dziecko, każdy dorosły człowiek może stać się twórczym podmiotem w świecie, o ile odkryje w sobie kreatywną moc działającego życia. Jeżeli tak się stanie, będzie on równie wdzięczny za uzyskane od życia oparcie w świecie, jak dziecko wdzięczne jest dorosłym za uzyskane od nich oparcie. Bez wielkiej wdzięczności nie byłoby samodzielnego budowania siebie i świata, o czym przekonuje się każdy, kto choć przez chwilę odnalazł w sobie twórcze pokłady chwili.

W filozofii Nietzschego dziecko jest wzorem czy synonimem nadczłowieka. Mimo że kruche i słabe, potrafi czerpać moc z życia i przez to samo staje się pełne iście nadludzkiej mocy. Aby stać się naprawdę wolnym, również Zaratustra, w pewnym sensie, musi ponownie się narodzić i stać się dzieckiem. Tylko w ten sposób może ukochać ludzi jako tych, którzy zostaną przezwyciężeni ze względu na nadczłowieka. W tym paradoksie kryje się nowa forma odpowiedzialności za przyszłość całego rodzaju ludzkiego. Jest to odpowiedzialność, która nie toleruje współczucia i litości wobec tego wszystkiego, co i tak przemija i musi odejść, gdyż takie są wymogi wiecznie zmieniającego się życia. Rozumiejąc to, Zaratustra mówi

30 Tamże, 40. Marcel Neusch zwraca uwagę na to, że nie należy utożsamiać Nietzscheańskiego dziecka z dzieckiem ewangelicznym, ponieważ są to symbole diametralnie różne: „Dziecko ewangeliczne nie zna buntu i nie przekroczyło stadium wielbienia: jest uśpione i uległe”, natomiast dziecko Nietzscheańskie „staje ponad buntem, gotowe do rozpoczęcia nowego życia, które jest pozbawionym zastrzeżeń »tak« wobec świata i samego siebie. Nie wyrywa się ku wartościom, które by od zawsze górowały nad jego życiem; jest ono porywem ku własnej przyszłości, której nie dostanie od nikogo innego poza sobą samym. Dziecko to symbol człowieka, który jest całkowicie tworzeniem siebie przez siebie". Dziecko Nietzscheańskie, „nie będące w niewoli jakiegoś »tak « wobec Boga ani nie skamieniałe w bezruchu czy odmowie, wolne od wszelkich więzów - stoi przed nieprzewidywalną przyszłością, gotowe do wyłonienia »nadczłowieka «". M. Neusch, U źródeł współczesnego ateizmu, tłum. z fr. A. Turowiczowa, Paris 1980, 144-145. Por. Mt 18, 1-5; Mk 10, 13-16. 
do ludzi: „Uc z ę was nadczłow ieka. Człowiek jest czymś, co musi zostać przezwyciężone. Co uczyniliście, żeby go przezwyciężyć? Dotąd wszystkie istoty stworzyły coś ponad siebie; chcecie być odpływem tej wielkiej fali i raczej do zwierzęcia powrócić niż człowieka przezwyciężyć? Czymże jest małpa dla człowieka? Pośmiewiskiem i sromem bolesnym. I tym samym powinien być człowiek dla nadczłowieka: pośmiewiskiem i wstydem bolesnym. Przebyliście drogę od robaka do człowieka i jeszcze wiele jest w was z robaka. Niegdyś byliście małpami i jeszcze dziś człowiek jest bardziej małpą niż jakakolwiek małpa. (...) Nadczłowiek jest sensem Ziemi (Sinn der Erde). Wasza wola [niech] powie: nadczłowiek niech będzie sensem Ziemi! Zaklinam was, bracia moi, po zostańcie wierni Ziemi" 31 .

Bardziej wyrazista wizja nadczłowieka zawarta jest w przypowieści $O$ widmie $i$ zagadce. Zaratustra jest świadkiem przerażającej sceny, mianowicie widzi tarzającego się na ziemi młodego pasterza, w którego gardło wgryzł się długi, czarny wąż. Podbiega do niego i próbuje uwolnić go od węża, lecz jego wysiłki są daremne. Wówczas instynktownie krzyczy do dławiącego się nieszczęśnika: „Gryź! Gryź! Głowę odgryź! Gryź!”32. Pasterz posłuchał głosu i odgryzł głowę, odrzucił ją daleko od siebie i skoczył na równe nogi. W tym momencie stała się rzecz dziwna, albowiem człowiek ten nie był już poprzednim pasterzem, nie był już nawet człowiekiem. Był to ktoś „przemieniony, opromieniony, który ś m i a ł s i ę !”, a ,jeszcze nigdy

31 KSA 4, 14 (Also sprach Zarathustra: Zarathustra's Vorrede, 3). Imperatyw posłuszeństwa wobec matki wszelkiego życia występuje też pod koniec pierwszej części dzieła i ma charakter ostatniej woli Zaratustry: „Pozostańcie wierni Ziemi (...) mocą waszej cnoty! Wasza darząca miłość i wasze poznanie niechaj służą sensowi Ziemi! O to was proszę i zaklinam". KSA 4, 99 (Also sprach Zarathustra I: Von der schenkenden Tugend, 2). Margot Fleischer solidaryzuje się z Nietzschem stwierdzając, że „»wierność Ziemi«, dla której tyle uczynił, rzeczywiście powinna być nakazem czasu”. M. Fleischer, Der „Sinn der Erde" und die Entzauberung des Übermenschen. Eine Auseinandersetzung mit Nietzsche, Darmstadt 1993, 264.

32 KSA 4, 201 (Also sprach Zarathustra III: Vom Gesicht und Rätsel, 2). 
na Ziemi żaden człowiek nie śmiał się tak, jak o n się śmiał!”33. Zaratustra długo nie może ochłonąć i ciągle jeszcze trawi go tęsknota za dopiero co usłyszanym śmiechem prawdziwie wolnego (nad) człowieka. Intensywnie poszukuje sensu zaistniałego zdarzenia. Co właściwie stało się w tej chwili? Czy była to tylko fikcja, czy też scena ta rozegrała się naprawdę? Zaratustra nie wie tego, podobnie jak nie wie, z kim - symbolicznie - ma tu do czynienia: „K i m jest ten człowiek, któremu w gardziel wpełznie wszystko, co najcięższe i najczarniejsze?"34. Ba, Zaratustra jeszcze nawet nie wie, czym $\mathrm{w}$ istocie zadławił się ten nadzwyczajny człowiek.

Pielgrzymowanie niestrudzonego proroka-coacha kończy się ekstatyczną chwilą Wielkiego Południa, przedstawioną w przypowieści Znak. Widzimy tam Zaratustrę, który wychodzi ze swej jaskini i doświadcza swoistego olśnienia, wskutek czego instynktownie przysiada na kamieniu leżącym u wejścia. Otaczająca go sceneria raptownie się zmienia i cisza wypełnia się hałasem zlatującego się ptactwa. Nie jest to jednak scena jak z filmu Hitchcocka, gdyż gołębie tulą się do niego, okazując mu miłość i oddanie. Nie zdając sobie z tego sprawy, Zaratustra broni się przed nimi, energicznie wymachując rękami. W trakcie wykonywania tych chaotycznych ruchów jego dłoń zanurza się w gęstej grzywie lwa. Wtedy też słyszy łagodny, przeciągły pomruk króla zwierząt. Zaratustra ze zdumieniem patrzy, jak lew, niczym wierny pies, przywarł do jego kolan, a gołębie delikatnie pieszczą go skrzydłami. Zwierzaki te niesfornie tulą się do niego z taką miłością, jakby od zawsze go znały i kochały. Dopiero wtedy uświadomił sobie, że jest to zapowiadany znak „śmiejącego się lwa ze stadem gołębi" 35 i w okamgnieniu przemieniło się jego serce. Pomyślał, że długo wyczekiwane dzieci (czyli przyszli nadludzie)

33 Tamże, 202.

34 Tamże.

35 KSA 4, 246 (Also sprach Zarathustra III: Von alten und neuen Tafeln, 1). Por. KSA 11, 413 (Nachlaß, 32 [14]). 
muszą być w pobliżu i na tę myśl ,jego serce zmiękło, a z oczu kapały łzy i spadały na dłonie"36. Były to łzy szczęścia z urzeczywistniającej się przepowiedni i zarazem $\mathrm{z}$ dokonanej przemiany wewnętrznej, wszak Zaratustra dojrzał już do bycia nadczłowiekiem. Odmieniony, powiedział radośnie: „»M ó j to poranek, mó $\mathrm{j}$ dzień świta; b ywaj mi, bywaj, moje Wielkie Południe!«-Tako rzekł Zaratustra i opuścił swą jaskinię, płomienny i potężny, jak słońce poranne, gdy spoza ciemnych wschodzi gór"37. To mistyczne doświadczenie jedności z całym stworzeniem można chyba uznać za przejaw wieczności, nie mającej „tu i teraz” żadnego określonego odpowiednika: „Wszystko to trwało przez długi lub krótki czas: ponieważ, prawdę mówiąc, dla tego rodzaju rzeczy na Ziemi nie istnieje $\dot{z}$ a d e $n$ czas" 38 .

\section{SYZYFOWA PRACA COACHA Z WIECZNIE POWRACAJĄCYM MAŁYM CZŁOWIEKIEM}

Zaratustra miłuje życie i wszystko, co żyje zgodnie ze swym własnym przeznaczeniem. Zwłaszcza nie brakuje mu pozytywnych uczuć wobec otaczających go zwierząt: „Każdego potwora chciałbyś pogłaskać. Jedno tchnienie ciepłego oddechu, trochę kudłów na łapie i zaraz byłeś gotowy to kochać i wabić"39. W jego życiu nadeszła pora na rozliczenie się z dotąd przeżytego życia. Czy było ono coś warte i czy chciałby znowu tak samo je przeżyć?: „Czy to było życie? Ejże! Jeszcze Jeden Raz!"40. Prorok nie tylko chce powrotu życia, ale chce jego wiecznego powracania. Nie jest to wyraz przywiązania do starożytnej idei wiecznego powrotu, charakteryzującej się mechanicystyczną

36 KSA 4, 407 (Also sprach Zarathustra IV: Das Zeichen).

37 Tamże, 408.

38 Tamże, 407.

39 KSA 4, 196 (Also sprach Zarathustra III: Der Wanderer).

40 KSA 4, 199 (Also sprach Zarathustra III: Vom Gesicht und Rätsel, 1). 
konsekwencją ${ }^{41}$. Filozofia Nietzschego rozszerza znaczenie tej formuły i każdy kolejny powrót uzupełnia o jakąś nową jakość, która góruje nad nieustannie namnażającą się ilością. W istocie jednak każdorazowo powraca to, co już jest jakoś nam znane, chociaż jeszcze nie znane do końca ${ }^{42}$. Podczas rozmowy Zaratustry z karłem, jego duchem ciężkości, prorok wyjawia swą otchłanną myśl, budzącą przerażenie u wszystkich śmiertelników. Scena ta rozgrywa się tuż przy bramie, w której zbiegają się dwie drogi, którymi jeszcze nikt nigdy nie szedł do końca. Jedna $\mathrm{z}$ nich biegnie z powrotem w nieskończoność, natomiast druga naprzód w nieskończoność. Drogi te więc „przeczą sobie”, jakby zderzając się głowami, a dokładnie nad

41 Jak zauważa Mircea Eliade, mit wiecznego powrotu zawiera w sobie metafizyczną prawdę, że „wszystko na powrót się zaczyna z każdą chwilą. Przeszłość to tylko prefiguracja przyszłości. Żadne wydarzenie nie jest nieodwracalne, żadna przemiana nie jest ostateczna. W pewnym sensie można nawet rzec, że w świecie nie dzieje się nic nowego, gdyż wszystko jest tylko powtarzaniem tych samych pierwotnych archetypów; owo powtarzanie, aktualizując moment mityczny, w którym archetypowy gest został objawiony, utrzymuje nieustannie świat w tej samej chwili brzasku początków. Czas jedynie umożliwia pojawienie się i istnienie rzeczy. Nie ma żadnego rozstrzygającego wpływu na to istnienie - ponieważ sam bez przerwy się odnawia”. M. Eliade, Mit wiecznego powrotu, tłum. z fr. K. Kocjan, Warszawa 1998, 103. Wytrawny badacz starożytnych kultur i fenomenu religijności dodaje, że „w filozofii Nietzsche przywraca mit wiecznego powrotu do porządku dziennego" (tamże, 158), ale jest to uproszczenie, ponieważ nietzscheańska wizja wielkiego powracania różni się od swego pierwowzoru.

42 Jak wiadomo, symbolem wiecznego powrotu jest uroboros - wąż zjadający własny ogon. W jednej z przypowieści czytamy, że Zaratustra otrzymał w pożegnalnym prezencie od ludzi wyższych specjalną laskę, "na której złotym uchwycie wąż wił się wokół słońca”. KSA 4, 97 (Z I: Von der schenkenden Tugend, 1). Zapewne na tej podstawie Rudolf Kreis uważa, że wąż Zaratustry to „uroboros, symbol niezniszczalnego życia i leczenia (Asklepios/ Eskulap). Jego przeciwieństwem jest zaś wąż poznania, wygłodzone zwierzę, które pożera Ziemię i które »dusiło « już Zaratustrę w dzieciństwie". R. Kreis, Der Nietzsche-Mythos vom Erdenreich. Gegen Gottesmord und Erdzerstörung, Frankfurt am Main 1991, 235. Warto zauważyć, że u Nietzschego wąż jako symboliczny obraz koliska czasu wyobraża także specyficzną wartość darzącej cnoty. Dawanie, nieoczekujące niczego w zamian, wywołuje analogiczny skutek, z jakim mamy do czynienia w przypadku wiecznego powrotu tego samego. 
nimi znajduje się napis „chwila” (Augenblick) ${ }^{43}$. Dlaczego chwila? Pewnie dlatego, że tylko jedną chwilę, jedno mgnienie oka trwa to, co jest teraz, zanim uleci w przeszłość, aby kiedyś znowu powrócić z przyszłości. Chwila jest zatem punktem na kołowrocie czasu, który łączy z sobą wszystkie zdarzenia $z$ niezgłębionego obszaru życia, pozwalając im periodycznie się urzeczywistniać. W tej nieco nielogicznej logice czasu człowiek dosięga granic nieskończoności i (tylko) wtedy uświadamia sobie potęgę stale na nowo stającego się bytu.

Zaratustra wie, że jego misją życiową jest głoszenie nauki o nadczłowieku i o wiecznym powrocie. Zarazem zdaje sobie sprawę $\mathrm{z}$ trudności, jakie wiążą się z tym niecodziennym posłannictwem. Przecież ludzie nie kwapią się, by się przezwyciężać i tak oto stawać się nadludźmi. Na dodatek działanie drugiej z wielkich idei Nietzscheańskich nie pozwala nigdy zapomnieć o człowieku, a nawet nachalnie zwielokrotnia jego pozornie nieistotne istnienie: „Wiecznie powraca on, człowiek, którym jesteś zmęczony, mały człowiek (...) ach, człowiek wiecznie powraca! Mały człowiek wiecznie powraca!"44. Wizja niemożności uporania się z powracającą małością człowieka powoduje, że wszystko staje się małe i bez znaczenia, wszelki byt staje się źródłem egzystencjalnego przesytu. Chociaż pielgrzymujący Zaratustra spotkał się z różnymi ludźmi, występujące między nimi różnice przestały mieć obecnie jakiekolwiek znaczenie. Przy konstytutywnej małości człowieka również wyższy człowiek jest jeszcze „nazbyt ludzki”45. Poza tym nie tak łatwo jest uwolnić się

43 KSA 4, 199-200 (Also sprach Zarathustra III: Vom Gesicht und Rätsel, 2). Pierre Klossowski pisze, że „dwie przeciwstawne drogi tworzą JEDNĄ; oddziela je wieczność: jednostki, rzeczy, zdarzenia wchodzą przez jedną, schodzą drugą i powracają takie same pod brama Chwili, wykonawszy krąg wieczności: ten, kto zatrzymuje się przed tą «bramą», jako jedyny zdolny jest uchwycić kolistą strukturę wiecznego czasu". P. Klossowski, Nietzsche i błędne koło, tłum. z fr. B. Banasiak i K. Matuszewski, Warszawa 1996, 117. Warto w tym kontekście wspomnieć, że chrześcijaństwo dysponuje podobnym co do formy symbolem, zawartym w przypowieści o dwóch drogach i bramie (Mt 7, 13-14; Łk 13, 24-30).

44 KSA 4, 274 (Also sprach Zarathustra III: Der Genesende, 2).

45 Tamże. 
od człowieka, który jest przyczyną wielkich, diametralnie różnych namiętności - gdy się go kocha i nienawidzi, odczuwa przesyt nim, ale i współczuje mu. Nieustannie balansując emocjonalnie między człowiekiem a nadczłowiekiem, Zaratustra lamentuje: „Jak zniosę żyć jeszcze! I jak zniósłbym to, żeby teraz umrzeć!”46. Być może nauki prorockie bliskie są tylko Zaratustrze, który tęskniąc za śmiechem wyzwolonego pasterza, właściwie tęskni za samym sobą, jako że w tejże wizji zobaczył swoją przyszłą, nadludzką postać. Nie tyle więc pasterzowi, ile jemu samemu coś wgryzło się w gardło. Co to było? W chwili Wielkiego Południa okazało się, że naprawdę dławiło go i zagrażało jego życiu przywiązanie do człowieka. Tę słabość (do ludzi) wykorzystuje wróżbiarz usiłujący skusić Zaratustrę do jego ostatniego grzechu, który skutkowałby zaprzepaszczeniem nauczycielskiej misji ${ }^{47}$. Perspektywa pojawienia się długo wyczekiwanych dzieci spowodowała jednak, że Zaratustra ochłonął i wziął sięw garść: „Współczucie! Współczucie z człowie k i e m w y ż s z y m! - wykrzyknął, i oblicze jego zmieniło się w spiż. Hejże! To już przeminęło! Moje czucie i współczucie - cóż mi na tym zależy!"48. Odtąd mówi odważne „tak” swemu przyszłemu ,ja” i każdemu, jakościowo nowemu „ty”, dając tym wyraz czystej miłości do samego siebie i do innych: „Kocham tych, którzy nie chcą zachować siebie. Ginących kocham całą moją miłością: ponieważ oni przechodzą dalej"49.

46 KSA 4, 202 (Also sprach Zarathustra III: Vom Gesicht und Rätsel, 2).

47 W jednej z zachowanych w Spuściźnie (Nachlaß) wersji autobiografii Ecce homo Nietzsche zawarł bardzo ważną wskazówkę ułatwiającą zrozumienie centralnej idei jego największego dzieła filozoficznego. Czytamy w niej: „Niebezpodstawnie jako »kuszenie Zaratustry« wymyśliłem pewien przypadek, kiedy to dochodzi do niego wielkie wołanie o pomoc, kiedy chce nim zawładnąć współczucie niczym ostatni grzech (...). Jest to próba, ostatnia próba, przez którą przed samym sobą musi przejść Zaratustra i ten, kto jest jemu równy". KSA 13, 621 (Nachlaß, 24 (1)).

48 KSA 4, 408 (Also sprach Zarathustra IV: Das Zeichen).

49 KSA 4, 251 (Also sprach Zarathustra III: Von alten und neuen Tafeln, 6). 
Większość ludzi bojaźliwie odsuwa od siebie perspektywę wzniesienia się ponad samych siebie, dlatego ich duch nigdy nie uleci w przestworza i nie będzie szybował niczym orzeł nad przepaścią. Ludzie ci nie doznają „,szczęścia w przestrachu ducha”, ale może i lepiej, ponieważ „kto nie jest ptakiem, nie powinien znajdować się nad przepaściami" 50 . Trzeba dysponować wielkim hartem ducha i mieć nadzwyczaj mężne serce, aby pokusić się o przekroczenie granicy zwyczajności, przed którą zatrzymują się ludzie przeciętni, nie ufający twórczej mocy życia. W wizji Nietzschego wszelkie zbiorowości ludzkie podobne są do wielkiego targowiska, na którym pozornie wiele się dzieje, ale w zasadzie wszystkie działania są do siebie bardzo podobne. Zwykle ludzie nie potrafią być naprawdę sobą, dlatego zwracają wielką uwagę na innych, usiłując się na nich wzorować. W rezultacie wszyscy biorą przykład ze wszystkich, z czego wprost nie wynika nic dobrego, a tym bardziej nic oryginalnie twórczego. Aliści równomierne pulsowanie życia na targowisku jest oczekiwaniem na coś lub na kogoś, kto odmieni tę nijakość i wyznaczy nowe wzorce zachowań. Najczęściej władzę nad szarą masą ludzką przejmują prowodyrzy o nader wątpliwej proweniencji i o lichych kwalifikacjach moralnych. Ludzie stają się posłuszni tym „aktorom” i „błaznom”, nie zdając sobie sprawy z tego, że ich idole mają w sobie

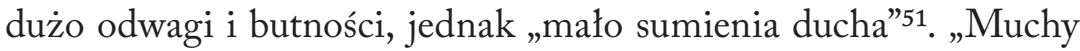
$\mathrm{z}$ targowiska" stają się bezwolnymi narzędziami swych prowodyrów, podobnie jak zmęczeni życiem stają się posłusznymi uczniami kaznodziejów śmierci. Złożenie własnego losu w ręce innych pozwala im uniknąć trudu samodzielnego kształtowania siebie i dbania o należyty rozwój swego ducha. Kto jednak nie potrafi bądź nie chce przyłożyć się do przezwyciężenia w sobie lęków i słabości, ten na zawsze pozostanie marionetką aktorów i błaznów. Nigdy już nie nada swemu życiu większego sensu i nie będzie realizował wyznaczonych przez

50 KSA 4, 134 (Also sprach Zarathustra II: Von dem berühmten Weisen).

51 KSA 4, 65 (Also sprach Zarathustra I: Von den Fliegen des Marktes). 
siebie wartości, a perspektywę własnej chwały całkowicie przesłoni tani blichtr sławy jakiegoś aktorzyny z targowiska. $Z$ uwagi na dobro człowieka Zaratustra chciałby wywrzeć nań presję i przymusić do zaakceptowania wyższych ideałów życiowych, jednak wie, że jest to rozwiązanie iluzoryczne, ponieważ wszyscy członkowie zbiorowości ludzkiej reprezentują takie same, bezwartościowe poglądy, od których nie mają ochoty odstąpić. Nie warto w ogóle zadawać się z nimi i tracić cennej mocy życia oraz czasu na jałowe spory: „Nie podnoś więcej ręki przeciwko nim! Są niezliczeni, a nie jest twoim przeznaczeniem stać się oganiaczką od much"52.

Wspominając swe spotkania z ludźmi, Zaratustra konstatuje: „Kiedy mówiłem do wszystkich, nie mówiłem do nikogo”53. Jego zaangażowanie misyjne i chęć nawracania tłumów było niczym „szaleństwo pustelnika”, samotnie stojącego na rynku i mówiącego do samego siebie. Wprawdzie dużo osób otaczało go, ale nikt nie zamierzał go słuchać, ponieważ nauka o nadczłowieczeństwie nie znajduje u małych ludzi posłuchu. Tłum zawsze żądny jest równości i domaga się, aby nikt nie przewyższał go pod żadnym względem. Mali ludzie to faktycznie tylko „słodziutkie, natrętne psy”54, szukające sposobu, aby unicestwić twórczy dystans między poszczególnymi jednostkami. Gdy Nietzsche konstruował program „hodowania” nadczłowieka, to poczynił założenie, że etapem pośrednim będzie powstanie wystarczającej ilości wyższych ludzi, mogących przygotować drogę przyszłemu, naprawdę wielkiemu człowiekowi. Powinni być to ludzie, którzy z gorącym sercem, wypełnionym niewzruszoną wolą rozwoju, poszukają w sobie tego, co w nich samych nadaje się jeszcze do przezwyciężenia. Ich duchową postawę znamionować ma zarówno „wesołość, cierpliwość, prostota i pogarda dla wielkich

52 Tamże, 66.

53 KSA 4, 356 (Also sprach Zarathustra IV: Vom höheren Menschen, 1). Tak oto wyjaśnia się Nietzscheańskie rozumienie podtytułu książki o proroku Zaratustrze.

54 KSA 4, 305 (Also sprach Zarathustra IV: Gespräch mit den Königen, 1). 
próżności”, jak i „wspaniałomyślność w zwycięstwie i pobłażanie dla małych próżności wszystkich zwyciężonych" 55 . Wyżsi ludzie nie mogą bać się życia, a zwłaszcza nie mogą lękać się niewiadomego, które czyha na nich na każdym kroku. Zadaniem tychże ludzi jest „żyć ni ebezpi e czni e!"56, tzn. doświadczać różnych życiowych możliwości i dzięki nim tworzyć własną egzystencję coraz pełniejszą i doskonalszą. Nietzsche mówi, że są to „bardziej zagrożeni ludzie, bardziej płodni ludzie, bardziej szczęśliwi ludzie" 57 . Ta wizja człowieka wolnego, jaką Nietzsche przedstawił w Wiedzy radosnej, nie zgadza się jednak z postacią rzeczywistego człowieka, którego spotyka prorok będący bohaterem Tako rzecze Zaratustra. Wyższy człowiek nadal jest małym człowieczkiem, który boi się odważniej spojrzeć w przyszłość, a tym bardziej rozstać się z własną małością na rzecz nadludzkiej wielkości. Nie ma on w sobie ani spokoju ducha, ani woli przezwyciężenia siebie, czyli niezbędnych warunków stania się pomostem do nadczłowieka. $Z$ nasienia wyższego człowieka ma wyrosnąć „,autentyczny syn i doskonały dziedzic: jest to jednak odległe" 58 , o czym Zaratustra nie raz się przekonuje.

U podłoża wszystkiego, co się rodzi i umiera, trwa niekończący się proces przezwyciężania tego, co chciałoby zachować siebie w niezmiennej i ostatecznie uformowanej postaci. Zaratustra odwołuje się do bodaj największej prawdy całego bytu: „Tę tajemnicę wyznało mi samo życie. »Spójrz, jestem tym, co się zawsze samo musi p r z e z w y c i ę ż a ć «"59. Oczywiście dla nas, ludzi, najważniejszym

55 KSA 3, 526 (Die fröhliche Wissenschaft, 4, 283).

56 Tamże. Neusch zauważa, że „podczas gdy ideał chrześcijański z góry wytycza szlak, ideał nietzscheański wyprawia w drogę nie podając kierunku. Każdy ma go wymyślić w marszu (...). I każdego człowieka zaprasza, by odtąd stał się twórcą (...). Człowiek nietzscheański to człowiek ryzyka. Odrzuca wszelką celowość. I sam wymyśla sobie cel życia”. M. Neusch, dz. cyt., 153.

57 KSA 3, 526 (Die fröhliche Wissenschaft, 4, 283).

58 KSA 4, 351 (Also sprach Zarathustra IV: Die Begrüssung).

59 KSA 4, 148 (Also sprach Zarathustra II: Von der Selbst-Überwindung). 
zadaniem jest nasze własne samoprzezwyciężenie ${ }^{60}$. W istocie polega ono na przemianie aktualnej jaźni w nową, wyższą i doskonalszą jaźń. Trzeba jednak mieć się na baczności, aby nie pobłądzić na tej drodze duchowego rozwoju. Nietzsche przestrzega, że formuła, w myśl której „wszystko przemija, dlatego wszystko warte jest tego, aby przeminęło" 61 , jest ewidentnym przejawem niedoboru woli mocy. Nie należy również zachłystywać się nadmiarem woli mocy i w dążeniu do jak najszybszej przemiany skupiać zbyt wielkiej uwagi wyłącznie na sobie. Kto o tym jeszcze nie wie, ten podobny jest do tygrysa, który przygotował się do skoku, ale w ostatniej chwili zrezygnował i wycofał się. Dlaczego nie zdecydował się skoczyć? Dlatego, że jest zbyt mocno napięty i przejęty koniecznością przemiany, wskutek czego nie potrafi „skoczyć ponad swój własny cień (...) we w ł a s n e słońce" 62 . Chcąc ostatecznie wygrać zawody z własnym cieniem, trzeba zrównoważyć w sobie moc życia. W postawie zwycięzcy jest coś z rezygnacji i coś z waleczności, ale obie te cechy muszą z sobą doskonale współgrać. Zdobywając dla siebie nowe obszary rozwoju i udoskonalając własną jaźń, należy postępować w duchu pokory i szacunku dla ziemskiego życia i dla wszystkiego, co żyje. Prawdziwy zwycięzca jest szczęśliwy, że życie dało mu szansę rozwoju, tyle że ,jego szczęście powinno pachnieć Ziemią, a nie pogardą dla Ziemi"63. Prawdziwy zdobywca śmieje się i ogarnia go wielka radość, ponieważ zdobył siebie, nie tracąc Ziemi, której zawdzięcza życie, i nie zatracając innych, którzy także pragną radować się życiem.

60 Kreis lakonicznie, ale bardzo zasadnie stwierdza, że „człowiekiem przyszłości jest dla Zaratustry człowiek samoprzezwyciężenia”. R. Kreis, dz. cyt., 236.

61 KSA 4, 180 (Also sprach Zarathustra II: Von der Erlösung). Jest to wyraźne nawiązanie do słów Mefistofelesa, będących wyrazem negacji świata: „Ja jestem duch, co zawsze mówi: nie. / I słusznie, wszystko bowiem, co powstaje, / Do wytępienia tylko się nadaje". J.W. Goethe, Faust, tłum. z niem. F. Konopka, Warszawa 1962, 104 [1344-1346].

62 KSA 4, 151 (Also sprach Zarathustra II: Von den Erhabenen).

63 Tamże. 
Radość proroka wiąże się z miłością do ludzi pragnących stać się nadludźmi. Są oni są jego prawdziwymi uczniami i posłusznie idą za nim, pilnie słuchając nauk o koniecznym samoprzezwyciężeniu. Właśnie do nich kieruje to bardzo ważne pouczenie: „Każda wielka miłość jest ponad każdą waszą litością: gdyż ona chce owo kochane ponadto stworzyć! »Siebie samego ofiarowuję swej miłości, i mojego bliźniego tak jak mnie«-taka jest mowa wszystkich twórców"64. Zamiast cieszyć się z posłuchu znalezionego u niewielkiej garstki uczniów, Zaratustra stwierdza, że każda forma przywiązania jest zła, niezależnie od tego, czy jest to przywiązanie do samego siebie, czy do fałszywego proroka, czy też do prawdziwego proroka. Znamienne są w tym względzie słowa pożegnalne, które Zaratustra wypowiada przed rozstaniem $\mathrm{z}$ tymi, jak się wydaje, wartościowymi ludźmi: „Sam idę teraz, moi młodzi! Wy także idźcie teraz stąd i [to] sami (...). Nakazuję wam, abyście mnie utracili i siebie odnaleźli; i dopiero gdy wszyscy się mnie wyprzecie, powrócę do was"65. Nie można stać się sobą, pozostając w zależności od kogoś innego, nawet jeżeli ten ktoś rzeczywiście jest dobrym wzorem osobowym i prawdziwym przewodnikiem duchowym. Paradoksalnie, w pewnych okolicznościach uczciwość wymaga swoistej niewierności. Przywołajmy w tym miejscu ważne przesłanie Nietzschego: „Każdy mistrz ma tylko jednego ucznia - $\mathrm{i}$ ten stanie się wobec niego niewierny, ponieważ jest również przeznaczony do bycia mistrzem"66. Dobry nauczyciel, któremu leży na sercu rozwój jego podopiecznych, musi w określonym czasie zezwolić im na samodzielne pokierowanie ich losem. Podobnie, ktokolwiek zamierza prawidłowo się rozwijać,

64 KSA 4, 116 (Also sprach Zarathustra II: Von den Mitleidigen).

65 KSA 4, 101 (Also sprach Zarathustra I: Von der schenkenden Tugend, 3). Te same słowa o wyparciu czy zaparciu się mistrza padają w autobiografii Nietzschego, zob. KSA 6, 261 (Ecce homo: Vorwort, 4). Jak zauważa Jaspers, „Nietzsche jest zatem od początku do końca »prorokiem«, który w przeciwieństwie do wszystkich innych proroków każdego odsyła do siebie samego". K. Jaspers, Nietzsche, dz. cyt., 24).

66 KSA 2, 522 (Menschliches, Allzumenschliches II, 1, 357). 
ten musi na pewnym etapie rozwoju porzucić swego nauczyciela. Dopiero wtedy będzie mógł doprowadzić do końca zadanie samoprzezwyciężenia i stanie się wystarczająco dojrzały, by skutecznie pomagać innym. $Z$ treści autobiografii Nietzschego wynika, że nauczający Zaratustra też się czegoś nauczył, mianowicie zrozumiał, że zanim uwierzy się w kogoś innego, trzeba najpierw uwierzyć $\mathrm{w}$ samego siebie. Bez głębokiej wiary w siebie daremna jest wiara w cokolwiek innego: „Nie szukaliście jeszcze siebie, a tu znaleźliście mnie. Tak czynią wszyscy wierzący, dlatego tak mało [warta] jest wszelka wiara"67.

Przebywanie $z$ innymi i budowanie $z$ nimi wspólnoty dusz napotyka na wiele przeciwności, z których bodaj najpoważniejszą jest niespójność jaźni człowieka chcącego być własnym twórcą. Przekonujemy się o tym na podstawie mowy $O$ drogach twórcy, zawierającej dużo osobistych doświadczeń proroka w zakresie samotnego przezwyciężania własnych ograniczeń oraz skutków wewnętrznego rozdarcia duszy. Zaratustra nie ukrywa, że na swej drodze pielgrzymowania miewał znacznie więcej kłopotów z sobą samym niż z innymi ludźmi: „Najgorszym wrogiem, jakiego możesz spotkać, będziesz zawsze sam dla siebie"68. Bycie twórcą wymaga odwagi zmierzenia się z bezkresną głębią samotności, która jest zasadniczą inspiracją dla wielkiej aktywności, ale może także stać się przyczyną uciążliwej pasywności. Tylko nieliczni twórcy mają tak olbrzymie zaufanie do życia, że potrafią sprostać wymogom samotniczej egzystencji. Każde przezwyciężanie własnych słabości jest pracą trudną, ale nie syzyfową, dlatego nie powinniśmy z niej rezygnować.

67 KSA 6, 261 (Ecce homo: Vorwort, 4).

68 KSA 4, 82 (Also sprach Zarathustra I: Vom Wege des Schaffenden). 


\section{ZAKOŃCZENIE}

$\mathrm{Na}$ drodze Nietzscheańskiego (samo)rozwoju, będącego nieustanną walką z własnymi słabościami, możliwe jest osiągnięcie wolności wewnętrznej i stanie się panem samego siebie. Ów pan, kojarzony $\mathrm{z}$ mocarnym nadczłowiekiem, jest $\mathrm{w}$ istocie wiecznym dzieckiem, które tworzy świat w zgodzie poruszeniami jego natury, a zatem ostatecznie - z obowiązującymi na Ziemi prawami rozwoju, a zwłaszcza $z$ prawami wiecznego stawania się $i$,wiecznego powrotu” wszystkich rzeczy. Nadludzkie „dziecko” pozostaje otwarte na świat, nie tylko ten świat akceptując, ale afirmując to wszystko, co przyczynia się do jego dobrostanu. Można chyba powiedzieć, że twórcza postawa nadczłowieka jest wyrazem dogłębnie pojętego i przeżytego ekologizmu. Jako taka, jest odpowiedzią na problemy wynikające $z$ degradacji środowiska naturalnego, które coraz dotkliwiej dotykają wszystkich mieszkańców Ziemi. Zrewidowany coaching (neocoaching) musi uwzględniać zarówno potrzeby pojedynczych osób, jak i potrzeby globalne. Zaratustra-Nietzsche jawi się jako niemal modelowy coach, który bez ckliwego litowania się i współczucia, czy też bez pospolitego biadolenia, stawia przed nami szczytne zadanie wzrastania ku iście nadludzkiej wolności, tworzenia nowych wartości i stawania się prawdziwą wartością dla świata ${ }^{69}$. Warunkiem powodzenia tej misji jest wyzbycie się tendencji eskapistycznych, sprowadzających się, w gruncie rzeczy, do traktowania życia na Ziemi jako jedynie mało ważnego etapu pośredniego, poprzedzającego finalną postać życia

69 Heidegger wskazuje na inspirującą rolę Nietzschego w tworzeniu nowych wartości współczesnego świata: „Między innymi pod wpływem Nietzschego filozofia akademicka końca XIX i początku XX w. staje się »filozofią wartości« i »fenomenologią wartości«. Same wartości jawią się jak rzeczy w sobie, które porządkuje się w »systemy«. Pomimo milczącego odrzucenia filozofii Nietzschego, wertowano jego pisma, zwłaszcza Zaratustrę, szukając owych wartości w sobie, aby z nich potem zbudować »etykę wartości«, »bardziej naukowo « niż uczynił to »nienaukowy filozof-poeta Nietzsche”. M. Heidegger, Nietzsche, Pfullingen 1961, t. 2, 98-99. 
wiecznego. Wyrazem troski o prawidłowy rozwój świata i nas samych w świecie jest również zadbanie o naszą cielesność, wszak nie jesteśmy ulotnymi bytami duchowymi i somatyczna „zwierzęcość” stanowi nasz istotny komponent osobowy. Pielgrzymujaccy prorok Zaratustra nakłania nas do samodzielnej pracy nad sobą, która zwykle wpisuje się w samotniczą egzystencję człowieka o nadludzkich nadziejach i zamiarach. Czytelnik quasi-biblijnego dzieła Nietzschego mógłby rozpocząć własne przezwyciężanie z pomocą właściwego coacha albo tylko z pomocą Zaratustry-coacha, a potem musiałby porzucić swego mistrza i stać się coachem dla samego siebie ${ }^{70}$. W ramach neocoachingu każdy człowiek ma szansę wyrosnąć ze swej ludzkiej małości i stać się godnym swego miana nadczłowiekiem. Pozostaje tylko pytanie: Komu się to w końcu uda?...

\section{BIBLIOGRAFIA}

Azadpur M., Who is Nietzsche's Zarathustra? On Philosophy, Morality, and the Persians, New Nietzsche Studies 3(1999), 69-82.

Biblia Tysiqclecia, Pallotinum, Poznań-Warszawa 1982.

Cicero M.T., Rozmowy tuskulańskie, w: tenże, Pisma filozoficzne, t. III, tłum. z łac.

W. Kornatowski, PWN, Warszawa 1961.

Diels H., Die Fragmente der Vorsokratiker. Griechisch und Deutsch, Weidmannsche Buchhandlung, Berlin 1922.

70 Jaspers wspomina „klątwę” Nietzschego, w której filozof ten odstrasza od siebie ludzi błyskawicą swej mądrości. Nietzsche nie chce, aby jego śladami szli ci, co nie mają własnej drogi. Każdy człowiek powinien odnaleźć w życiu, a zwłaszcza w sobie samym swą własną prawdę. Stąd Jaspers pisze: „To nie jest przyjemne zakończenie, wraz z którym Nietzsche wypuszcza [nas] na wolność. To tak, jakby odmówił nam siebie. Wszystko zależy od nas. Prawdziwe jest tylko to, co dzięki Nietzschemu wychodzi z nas samych". K. Jaspers, Nietzsche a chrześcijaństwo, w: tenże, Rozum i egzystencja. Nietzsche a chrześcijaństwo, tłum. z niem. Cz. Piecuch, Warszawa 1991, 256; zob. KSA 4, 360 (Also sprach Zarathustra IV: Vom höheren Menschen, 7). Błyskawica Nietzscheańskiej mądrości, dzięki której on sam zobaczył nową wizję świata może więc oślepić tych, którzy nie potrafią własnymi oczami zobaczyć autentycznych wartości życiowych. 
Eliade M., Mit wiecznego powrotu, tłum. z fr. K. Kocjan, Wydawnictwo KR, Warszawa 1998.

Fleischer M., Der „Sinn der Erde” und die Entzauberung des Übermenschen. Eine Auseinandersetzung mit Nietzsche, Wissenschaftliche Buchgesellschaft, Darmstadt 1993.

Goethe J.W., Faust, tłum. z niem. F. Konopka, PIW, Warszawa 1962.

Harper M., Tak jak na poczatku. Z dziejów przebudzenia pentekostalnego w XX wieku (bwmrw).

Heidegger M., List o „humanizmie”, tłum. z niem. J. Tischner, w: tenże, Znaki drogi, Fundacja Aletheia, Warszawa 1995.

Heidegger M., Nietzsche, Verlag Günther Neske, Pfullingen 1961.

Homer, Iliada, tłum. z gr. K. Jeżewska, Ossolineum, Wrocław 1986.

Jaspers K., Nietzsche. Wprowadzenie do rozumienia jego flozofi, thum. z niem. D. Stroińska, Wydawnictwo KR, Warszawa 1997.

Jaspers K., Nietzsche a chrześcijañstwo, w: tenże, Rozum i egzystencja. Nietzsche a chrześcijaństwo, tłum. z niem. C. Piecuch, PWN, Warszawa 1991.

Klossowski P., Nietzsche i btędne koto, tłum. z fr. B. Banasiak i K. Matuszewski, Wydawnictwo KR, Warszawa 1996.

Kreis R., Der Nietzsche-Mythos vom Erdenreich. Gegen Gottesmord und Erdzerstörung, Verlag Peter Lang, Frankfurt am Main 1991.

Łyko Z., Nauki Pisma Świętego, Znaki Czasu, Warszawa 1989.

Mickiewicz A., Wiersze, Czytelnik, Warszawa 1970.

Neusch M., U źródet wspótczesnego ateizmu, tłum. z fr. A. Turowiczowa, Éditions du Dialogue, Paris 1980.

Nietzsche F., Sämtliche Briefe. Kritische Studienausgabe in 8 Bänden, red. G. Colli, M. Montinari, Verlag Walter de Gruyter, Berlin 1986 (skrót: KSB).

Nietzsche F., Sämtliche Werke. Kritische Studienausgabe in 15 Bänden, red. G. Colli, M. Montinari, Verlag Walter de Gruyter, Berlin 1988 (skrót: KSA).

Sherrill J. i E., Najszczęśliwsi na świecie. Fascynująca historia Demosa Shakariana (bwmrw).

Statut Stowarzyszenia „Polskie Stowarzyszenie Trenerów Rozwoju Osobistego", https:// icf.org.pl/o-nas/statut-stowarzyszenia/.

Teilhard de Chardin P., Moja wizja świata, w: tenże, Moja wizja świata i inne pisma, tłum. z fr. M. Tazbir, PAX, Warszawa 1987.

Uwolnij potencjat, ulotka promocyjna, International Coach Federation (bmrw). 


\title{
BECOMING YOURSELF ON THE PATH OF SELF-OVERCOMING. A PROJECT OF RADICAL ANTHROPOLOGY IN THE (NEO)COACHING
}

\begin{abstract}
Contemporary coaching works quite well in educational and therapeutic practice, but it lacks a solid anthropological foundation, i.e. an adequate concept of man that could become the basis for constructive (self)development in the spirit of authentic freedom. It seems that Friedrich Nietzsche's concept of overman could be usefully employed in coaching theory. The overman awaited by Zarathustra is a man who overcomes his own weaknesses and is able to act creatively in the world, guided by a sense of responsibility for the Earth. By using this concept of (over)man, the coach could effectively help his mentees and raise them "towards freedom”, without making them dependent on any psychological, social or ethical doctrine.
\end{abstract}

Keywords: coaching, philosophical anthropology, Nietzsche, overman, eternal return, self-overcoming, freedom

\author{
HENRYK BENISZ \\ benisz@uni.opole.pl \\ Uniwersytet Opolski, Wydział Nauk Społecznych \\ ul. Oleska 48, 45-052 Opole \\ ORCID: 0000-0001-5449-0760
}

DOI: 10.21697/spch.2020.56.2.02 